\title{
COMMENTARY
}

\section{Purification methods: a way to treat severe acute inflammation related to sepsis?}

Anne Claire Lukaszewicz and Didier Payen*

\begin{abstract}
After numerous negative randomized trials testing drugs for severe sepsis and/or septic shock, the blood purification approach remains one possibility. Many techniques have been proposed, having in common the goal to eliminate blood and/or plasma factors, supposed to play a negative role in outcomes. Among these, high dose of hemofiltration, high volume hemofiltration, high permeability hemofiltration and specific or non-specific hemoperfusion or hemoadsorption have been proposed. Until now, a poor level of proof has been published, questioning the pertinence of such a strategy. To have a chance to succeed, immune monitoring has to be performed to select suitable patients regarding their immune status, the intensity of inflammation and their cellular function. Because of the potential interaction with mediators and cell capture, Rimmelé and colleagues published the results obtained with an in vitro set up, testing different adsorption cartridges in comparison to hemofiltration. They nicely confirmed the complex impact on mediator levels and cell capture and phenotype. This is certainly a more systematic approach to better understand the action of such adsorbing cartridges, which has to be developed.
\end{abstract}

Blood as a target for adjuvant therapies, such as 'purification methods', for the treatment of acute inflammation related to severe infection has been proposed for many years, even with relatively low levels of proof [1-4]. Arguments for such an approach can be summarized as follows: almost all markers and cell phenotypes have been studied in blood; ex vivo studies using plasma from severe septic patients induce healthy cell phenotype changes mimicking those observed in septic cells [5];

*Correspondence: dpayen1234@orange.fr

Department of Anesthesiology \& Critical Care \& SAMU, Hôpital Lariboisière; AP-HP, EA 3509; Université Paris 7 Denis Diderot, 2 rue Ambroise Paré, Paris 75010, France plasma ultra-filtrate coming from septic patients induces ex vivo modification of cell functions [6]; and plasmapheresis therapy has been shown to be efficient at controlling auto-immune disease [7]. If these blood purification techniques are technically feasible, the mechanism(s) by which they can improve outcome remains unclear, and the goals of these techniques have to be clarified: reduction of activated circulating cells and/or removal of mediators, or a combination of the two, need to be clearly demonstrated [8]. This key question guides development of the technical strategy to achieve this goal: cell reduction requires supports for trapping cells while mediator removal requires membranes that adsorb mediators or allow them to cross [9]. Since sepsis mechanisms are still incompletely understood, particularly the impact of changing the levels of mediators on outcome, it is difficult to define the adequate support and methods. In addition, inflammatory patterns during sepsis are not stable over time, moving rapidly from hyper-inflammation to immune-suppression [10].

The article from Rimmelé and colleagues [11] reports the consequences on cytokine profiles and cell-cell interactions of an ex vivo device to capture blood leukocytes and cytokines in blood from septic patients compared to healthy volunteers. This experiment reveals new information using a whole blood heparinized circulation device, with two different hemoadsorption devices (cytosorb with large polystyrene beads, cytosorb with small polystyrene beads) compared to a hemofilter (Oxiris ${ }^{\circ}$, Gambro-Hospal) as a control, flowing at $0.75 \mathrm{ml} /$ minute. The surface polarity was modified to obtain a positively charged membrane to catch negatively charged endotoxins, when contact area was small for large beads. Using electron microscopy and immunofluorescence staining with confocal imaging, leukocyte capture can be characterized. Plasma cytokine levels were determined by the luminex technique, allowing a large panel of mediators to be measured. A large panel of leukocyte surface markers was studied by flow cytometry and appropriate antibodies. It was then possible to assess the effects of leukocyte removal on inflammation and immune function. The authors concluded that monocyte and leukocyte capture results in upregulation of interleukin-8 modulation of 
cell-mediated immunity. Both aspects, cell capture and mediator removal or release, appear feasible, but have to deal with time-dependent changes in the immune profile and also with the characteristics of circulating cells. Recent studies on functional genomic [12] and blood and tissue infiltrating immune cells [13] strongly suggest that the initial phase of sepsis or acute inflammation has a short duration, rapidly followed by quasi-constant immune depression during acute inflammation. Such induced immunodepression concerns all aspects of the inflammatory response, especially involving neutrophils, monocytes, and lymphocytes. The cell number, their function and life span become largely modified [9], with increasing life span of neutrophils, reduced function of monocytes and reduced life span and function of lymphocytes. The latter effect concerns the entire lymphocyte repertoire, except CD4+CD25+foxP3+ cells $[14,15]$. These observations question the timing for using hemoadsorption in severe sepsis, since the delay between the onset of sepsis and a therapeutic decision might be highly variable. Looking at the results obtained, such an extracorporeal device seems to perform well and is a promising method. For clinical use, it will then be essential to determine which patients, when, and for how long this strategy has to be applied. Such goals necessitate easy and repetitive immune monitoring, a major step to clarify. In addition, such a device has to work enough to overcome whole body production of mediators and cell phenotype changes. Considering the more or less selective removal of cells and mediators, the question might be: can plasmapheresis be a good alternative, especially if albumin is used as a replacement fluid? This hypothesis might be supported by the recently reported results of an Italian randomized clinical trial on albumin (Albios). The first report at the SMART meeting in May showed an outcome benefit in septic shock patients treated with albumin at a dose to obtain a plasma level close to $30 \mathrm{~g} / \mathrm{ml}$.

Competing interests

The authors declare that they have no competing interests.

Published: 21 June 2013

\section{References}

1. Payen D, Mateo J, Cavaillon JM, Fraisse F, Floriot C, Vicaut E: Impact of continuous venovenous hemofiltration on organ failure during the early phase of severe sepsis: a randomized controlled trial. Crit Care Med 2009, 37:803-810
2. Peng ZY, Wang HZ, Carter MJ, Dileo MV, Bishop JV, Zhou FH, Wen XY, Rimmelé T, Singbartl K, Federspiel WJ, Clermont G, Kellum JA: Acute removal of common sepsis mediators does not explain the effects of extracorporeal blood purification in experimental sepsis. Kidney Int 2012, 81:363-369.

3. Rimmele T, Kellum JA: High-volume hemofiltration in the intensive care unit: a blood purification therapy. Anesthesiology 2012, 116:1377-1387.

4. Borthwick EM, Hill CJ, Rabindranath KS, Maxwell AP, McAuley DF, Blackwood B: High-volume haemofiltration for sepsis. Cochrane Database Syst Rev 2013, 1:CD008075.

5. Belikova I, Lukaszewicz AC, Faivre V, Damoisel C, Singer M, Payen D: Oxygen consumption of human peripheral blood mononuclear cells in severe human sepsis. Crit Care Med 2007, 35:2702-2708.

6. Gomez A, Wang R, Unruh H, Light R, Bose D, Chau T, Correa E, Mink S: Hemofiltration reverses left ventricular dysfunction during sepsis in dogs. Anesthesiology 1990, 73:671-685.

7. Toft P, Schmidt R, Broechner AC, Nielsen BU, Bollen P, Olsen KE: Effect of plasmapheresis on the immune system in endotoxin-induced sepsis. Blood Purif 2008, 26:145-150.

8. Ono S, Kimura A, Hiraki S, Takahata R, Tsujimoto H, Kinoshita M, Miyazaki H, Yamamoto J, Hase K, Saitoh D: Removal of increased circulating CD4+CD25+Foxp3+ regulatory T cells in patients with septic shock using hemoperfusion with polymyxin B-immobilized fibers. Surgery 2013, 153:262-271.

9. Namas R, Zamora R, Namas R, An G, Doyle J, DickTE, Jacono FJ, Androulakis IP, Nieman GF, Chang S, Billiar TR, Kellum JA, Angus DC, Vodovotz Y: Sepsis: Something old, something new, and a systems view. J Crit Care 2012, 27:314 e311-311.

10. Hotchkiss RS, Monneret G, Payen D: Immunosuppression in sepsis: a novel understanding of the disorder and a new therapeutic approach. Lancet Infect Dis 2013, 13:260-268.

11. Rimmelé T, Kaynar AM, McLaughlin JN, Bishop JV, Fedorchak MV, Chuasuwan A, Peng Z, Singbartl K, Frederick DR, Zhu L, Carter M, Federspiel WJ, Zeevi A, Kellum JA: Leukocyte capture and modulation of cell-mediated immunity during human sepsis: an ex vivo study. Crit Care 2013, 17:R59.

12. Xiao W, Mindrinos MN, Seok J, Cuschieri J, Cuenca AG, Gao H, Hayden DL, Hennessy L, Moore EE, Minei JP, Bankey PE, Johnson JL, Sperry J, Nathens AB, Billiar TR, West MA, Brownstein BH, Mason PH, Baker HV, Finnerty CC, Jeschke MG, López MC, Klein MB, Gamelli RL, Gibran NS, Arnoldo B, Xu W, Zhang Y, Calvano SE, McDonald-Smith GP, et al:: A genomic storm in critically injured humans. J Exp Med 2011, 208:2581-2590.

13. Boomer JS, To K, Chang KC, Takasu O, Osborne DF, Walton AH, Bricker TL, Jarman SD 2nd, Kreisel D, Krupnick AS, Srivastava A, Swanson PE, Green JM, Hotchkiss RS: Immunosuppression in patients who die of sepsis and multiple organ failure. JAMA 2011, 306:2594-2605.

14. Venet F, Chung CS, Kherouf H, Geeraert A, Malcus C, Poitevin F, Bohe J, Lepape A, Ayala A, Monneret G: Increased circulating regulatory T cells (CD4(+)CD25 (+)CD127 (-)) contribute to lymphocyte anergy in septic shock patients. Intensive Care Med 2009, 35:678-686.

15. Venet F, Pachot A, Debard AL, Bohe J, Bienvenu J, Lepape A, Monneret G: Increased percentage of $\mathrm{CD} 4+\mathrm{CD} 25+$ regulatory $T$ cells during septic shock is due to the decrease of CD4+CD25- lymphocytes. Crit Care Med 2004, 32:2329-2331.

doi:10.1186/cc12757

Cite this article as: Lukaszewicz AC, Payen D: Purification methods: a way to treat severe acute inflammation related to sepsis? Critical Care 2013, 17:159. 